Vol. 16, No. 2 April 1966 pp. 171-172

\title{
INDOL PRODUCTION BY BACTERIA
}

\author{
Einar Leifson \\ Department of Microbiology, Stritch School of Medicine and \\ Graduate School, Loyola University, Chicago, Illinois
}

ABSTRACT. Production of indol by bacteria appears to be limited to those which produce acid from glucose fermentatively and reduce nitrate. From more limited experience, Gram-positive and pigmented bacteria did not produce indol.

Frieber (1952) published a list of bacterial characteristics which he had found to be associated with indol production: All indol positive cultures grow aerobically, do not produce spores, are Gram-negative, produce acid from glucose and reduce nitrate. Unfavorable to indol production are capsulation, pigment production and acidfastness. Henriksen (1952), however, reported that a number of his cultures of anaerobic bacteria of the genera Fusobacterium and Bacteroides produced indol, and also that many capsulated bacteria produced indol, such as species of Klebsiella, Escherichia, and Haemophilus influenzae.

My own experience in this regard has been mainly with fresh-water and marine bacteria which grow aerobically. Most of these bacteria were Gram-negative, straight or slightly curved motile rods. From a study of about 300 cultures of fresh-water bacteria and about 1,000 cultures of marine bacteria, indol production was found to be strictly limited to the fermentative types. Cultures which produced acid from glucose oxidatively or produced no detectable acid (using the $\mathrm{O}-\mathrm{F}$ medium) did not produce indol by the usual tests with paradimethylaminobenzaldehyde in amyl alcohol (Kovac reagent). In other words, indol production was limited to facultative types and the strict aerobes did not produce indol. In agreement with Frieber, all indol producers in my collection reduced nitrate.

In agreement with Henriksen but not with Frieber, many of the marine bacteria which produced indol were also encapsulated. My experience with Gram-positive bacteria is 
limited: a study of some 70 strains of Listeria did not show any which produced indol, nor have I any record of aerobic spore-formers which produce indol. Regarding pigment production, I have no definitely pigmented cultures which produce indol. Pigment production by fermentative bacteria is mainly limited to the genera Serratia and Chromobacterium, which in my experience, and from reports in the literature, do not produce indol.

The inability of nonfermenters to produce indol would make any report of indol production by species of the following genera very suspect: Pseudomonas, Xanthomonas, Achromobacter, Agrobacterium, Alcaligenes and several other genera less well defined.

\section{REFERENCES}

Frieber, W. 1952. Indolbildung bei bakterien. Internatl. Bull. Bact. Nomen. and Taxon. 2(3):94-95.

Henriksen, S. D. 1952. Indol production of bacteria.

Internatl. Bull. Bact. Nomen. and Taxon. 2(4):141-142. 